\title{
Seroprevalence of Toxoplasma gondii in cats (Felis catus, Linnaeus 1758) living in Lima, Peru
}

Soroprevalência de Toxoplasma gondii em gatos (Felis catus, Linnaeus 1758) residentes em Lima, Peru

Luis Cerro ${ }^{1 *}$; Alicia Rubio ${ }^{2}$; Rosa Pinedo ${ }^{3}$; Flavya Mendes-de-Almeida ${ }^{4}$; Beatriz Brener ${ }^{5}$; Norma Labarthe ${ }^{6}$

${ }^{1}$ Programa de Pós-graduaçáo em Medicina Veterinária, Faculdade de Veterinária, Universidade Federal Fluminense - UFF, Niterói, RJ, Brasil

${ }^{2}$ Departamento de Patología Clínica, Universidad Científica del Sur - UCSur, Lima, Perú

${ }^{3}$ Laboratorio de Microbiología y Parasitología Veterinaria, Facultad de Medicina Veterinaria,

Universidad Nacional Mayor de San Marcos, Lima, Perú

${ }^{4}$ Curso de Pós-graduação em Medicina Veterinária, Faculdade de Veterinária, Universidade Federal Fluminense - UFF,

Niterói, RJ, Brasil

${ }^{5}$ Departamento de Microbiologia e Parasitologia, Universidade Federal Fluminense - UFF, Niterói, RJ, Brasil

${ }^{6}$ Programa Biodiversidade \& Saúde, Fundação Oswaldo Cruz - Fiocruz, Rio de Janeiro, RJ, Brasil

Received June 9, 2013

Accepted December 5, 2013

\begin{abstract}
The aim of this study was to determine the frequency of infection by $T$. gondii in cats, by examining serum and fecal samples from animals attended at veterinary clinics in the Metropolitan Region of Lima, Peru. We collected and analyzed 154 cat serum samples and 50 fecal samples, regardless of the age, gender or breed. In parallel with the sample collections, the owners answered an epidemiological questionnaire that investigated the following variables: age group, gender, lifestyle (confined, semi-confined or free-living animals), feeding and hunting habits. The serum and fecal samples were analyzed using indirect hemagglutination (IHA) and coproparasitological tests, respectively. IHA showed that the frequency of cat exposure to T. gondii was $11 \%$. Age and gender showed no association with exposure to the parasite. Exposure among the cats was associated with hunting $\left(x^{2}=4.98, \mathrm{p}=0.016\right)$ and feeding habits $\left(\mathrm{x}^{2}=13.34\right.$, $p=0.001)$ : those fed with raw meat were more exposed than those fed with commercial cat food $\left(x^{2}=9.50, p=0.004\right)$ or with homemade food $\left(\mathrm{x}^{2}=4.1, \mathrm{p}=0.027\right)$. The frequency of cats diagnosed in the chronic phase of $T$. gondii infection was $88 \%(15 / 17)$. No T. gondii oocysts were found in any of the 50 fecal samples examined.
\end{abstract}

Keywords: Toxoplasma gondii, Lima, Peru, Indirect Hemagglutination, cats.

\section{Resumo}

O objetivo do presente trabalho foi determinar a frequência sorológica e coproparasitológica da toxoplasmose em gatos atendidos em clínicas veterinárias na região metropolitana de Lima, Peru. Foram analisadas 154 amostras de soros de gatos e 50 amostras de fezes de gato, independentemente da idade, gênero ou raça. Paralelamente ao ato da coleta, os proprietários responderam a um questionário epidemiológico onde foram tratadas as seguintes variáveis: faixa etária, gênero, estilo de vida (animais confinados, semiconfinados o de vida livre), hábitos alimentares e de caça. Os soros e amostras fecais foram analisados pelos testes de hemaglutinação indireta (HAI) e coproparasitológico, respectivamente. A frequência de gatos expostos foi $11,0 \%$, segundo HAI. As variáveis de faixa etária e sexo não mostraram associação com a exposição ao parasito. A exposição dos animais mostrou associaçáo com hábitos de caçar $\left(\mathrm{x}^{2}=4.98, \mathrm{p}=0.016\right) \mathrm{e}$ alimentação $\left(\mathrm{x}^{2}=13.34, \mathrm{p}=0.001\right)$, sendo aqueles alimentados com carne crua os mais expostos, quando comparados aos alimentados com ração $\left(x^{2}=9.50, \mathrm{p}=0.004\right)$ ou com comida caseira $\left(\mathrm{x}^{2}=4.1, \mathrm{p}=0.027\right)$. A frequência de gatos na fase crônica da infecção por $T$. gondii foi 88\% (15/17). Não foram achados oocistos de Toxoplasma gondii em nenhuma das 50 amostras de fezes.

Palavras-chaves: Toxoplasma gondii, Lima, Peru, Hemaglutinação indireta, gatos.

\footnotetext{
*Corresponding author: Luis Cerro

Programa de Pós-graduaçấo em Medicina Veterinária, Universidade Federal

Fluminense - UFF, Rua Vital Brasil Filho, 64, Santa Rosa,

CEP 24230-340, Niterói, RJ, Brasil

e-mail: 1cerro@gmail.com
} 
The worldwide distribution of Toxoplasma gondii crosses political boundaries and environmental conditions, and results in worldwide distribution of toxoplasmosis. Infection with this protozoon is one of the most common parasitic infections of humans and other warm-blooded animals (DUBEY; BEATTIE, 1988).

Its life cycle is divided into a sexual stage that occurs in the epithelial cells of the small intestine of Felidae, resulting in formation of oocysts that are shed in their feces, and an asexual phase that occurs in extraintestinal tissues of mammals or birds (ACHA; SZYFRES, 2003). Over one million non-sporulated oocysts can be dispersed to the environment in cat feces (DUBEY; FRENKEL, 1972). When environmental conditions are favorable (water, wetland, average temperature of $25^{\circ} \mathrm{C}$, and enough oxygen), the sporulated oocysts become infective within three days, thus explaining the high incidence of infection in tropical or subtropical areas (LEGUÍA, 2002).

The high rate of seropositivity among some feline populations can be explained by environmental contamination by oocysts, and consequently, elevated concentration of infective agents in food and water, which may reflect high rates of infection with T. gondii in intermediate hosts (PENA et al., 2006). However, it needs to be borne in mind that, contrary to common belief, immunocompetent cats only eliminate oocysts in their feces over the course of primary infection (3-20 days in their lives). Therefore, areas inhabited by seropositive cats tend to express lower parasite loads (DUBEY, 1994a, 1996).

The animal infection rates obtained in different countries around the world are influenced by different factors such as geographic location (higher rates in tropical zones) (GONDIM et al., 1999; MARTÍN-HERNÁNDEZ; GARCÍA-IZQUIERDO, 2003; SILVA et al., 2003), public cultural habits (ingestion of raw or undercooked meat and untreated water) (DUBEY, 1988), type of fauna, infrastructure and the degree of development of the area. In this light, serum and fecal samples from household cats were assayed to determine the frequency of exposure to $T$. gondii, using commercial hemagglutination and coproparasitological tests, respectively. This was done to test the serological and coproparasitological prevalence of feline toxoplasmosis as an indicator of parasite spreading in the Metropolitan Region of Lima, Peru.

The project was authorized by the Ethics Committee for Animal Research, Dean's Office for Research and Postgraduate Studies, Universidade Federal Fluminense, Niterói, RJ, Brazil.

The survey was conducted in the Metropolitan Region of Lima, Peru ( $\left.12^{\circ} 02^{\prime} S, 77^{\circ} 01^{\prime} \mathrm{W}\right)$. After owners' consent had been obtained, 154 cats, irrespective of age, breed, gender, and health status were sampled for blood and 50 of these, for feces. The survey data form was completed by including information on gender, lifestyle (confined, semi-confined or free) (MENDESDE-ALMEIDA et al., 2005), age, diet and hunting habits. The animals were categorized as young ( $<1$ year), adult ( $1-7$ years) and over 7 years old (HAND et al., 2000). Diet was categorized as: (i) cat food, those that were exclusively fed with commercial diet; (ii) homemade food, those fed with homemade food or homemade food and commercial diet; or (iii) raw meat, those also fed with raw meat in addition to other sources.
Screening for antibodies was performed using the indirect hemagglutination (IHA) test (TOXO HAI-Lab', Analisa, Belo Horizonte, Brazil), following the manufacturer's instructions. Fecal samples were processed by means of the FAUST technique (FAUST et al., 1938).

A database was created, using EPI INFO 2002 (CDC, 2002), which included the identification data of each animal (sex, age, eating habits, lifestyle and hunting habits) and laboratory test results. The data were subjected to exploratory analysis (MEDRONHO et al., 2002) and later to the chi-square and Fisher Exact statistical tests (SAMPAIO, 2002), to investigate the existence of associations between the variables.

A total of 17 cats were tested positive for $T$. gondii antibodies (11\%). The variables of age and gender did not show any association with exposure. In the Metropolitan Region of Lima, exposure of animals was associated with hunting habits $\left(x^{2}=4.98, p=0.016\right)$ and feeding habits $\left(x^{2}=13.34, p=0.001\right)$. Cats that were fed with raw meat were more exposed than those fed with commercial food $\left(x^{2}=9.50, p=0.004\right)$ or homemade food $\left(x^{2}=4.1, p=0.027\right)$ (Table 1).

The majority of the exposed cats $(88 \% ; 15 / 17)$ only showed markers of past exposure ( $\mathrm{IgG})$. Interestingly, the two animals that were identified with acute-phase markers (2/17) were more than seven years old.

Since this parasitic species is undemanding with regard to environmental conditions, it is considered to persist with greater frequency in warm humid areas (MARTÍN-HERNÁNDEZ;

Table 1. Absolute and relative frequencies of antibodies to Toxoplasma gondii according to the indirect hemagglutination (IHA) test, distributed according to the variables of age, gender, lifestyle, diet and habit of hunting, among cats in the Metropolitan Region of Lima, Peru, 2011.

\begin{tabular}{lccc}
\hline \multicolumn{1}{c}{ Variables } & \multicolumn{3}{c}{ Lima } \\
\cline { 2 - 4 } & Total & Positive & $\% \pm$ IC \\
\hline Age & 154 & 17 & $11.0 \pm 4.9$ \\
$<1$ year & & & \\
1 year-7 years & 49 & 3 & $6.1 \pm 6.7$ \\
$>7$ years & 62 & 6 & $13.9 \pm 10.3$ \\
Gender & & 8 & $12.9 \pm 8.3$ \\
Male & 79 & 11 & $13.9 \pm 7.6$ \\
Female & 75 & 6 & $8.0 \pm 6.1$ \\
Lifestyle & & & \\
Confined & 107 & 9 & $8.4 \pm 5.2$ \\
Semi-confined or free & 47 & 8 & $17.0 \pm 10.7$ \\
Feeding & & & \\
Commercial food & 111 & 9 & $8.1^{\mathrm{a}} \pm 5.0$ \\
Homemade food & 35 & 4 & $11.4^{\mathrm{a}} \pm 10.5$ \\
Raw food & 8 & 4 & $50.0^{\mathrm{b}} \pm 34.6$ \\
Hunting & & & \\
Yes & 42 & 9 & $21.4^{\mathrm{a}} \pm 12.4$ \\
No & 112 & 8 & $71.4^{\mathrm{b}} \pm 4.7$ \\
\hline Difert & & & \\
\hline
\end{tabular}

Different letters in columns indicate $95 \%$ significance, in relation to the same variable. 
GARCÍA-IZQUIERDO, 2003). These are ideal conditions for maintaining the viability of the oocysts. A previous study (DUBEY, 1994a) demonstrated that oocysts could remain viable at temperatures between 10 and $25^{\circ} \mathrm{C}$, which makes it clear that the Metropolitan Region of Lima has ideal conditions for development and survival of the parasite.

This parasitic species shows high adaptability to its environment. These adaptability skills are demonstrated by the fact that it has been reported on every continent of the planet, except for certain Pacific islands where there are no definitive hosts (WALLACE, 1969). Thus, cats are important sources for maintenance of the parasite species in urban areas, regardless of region, since the species is found worldwide.

The sex and age of the hosts did not have any influence on exposure rates, which was expected (DEEB et al., 1985; GARCIA et al., 1999; OVALLE et al., 2000; GAUSS et al., 2003). Nonetheless, it has been suggested that males are more exposed than females (MIRÓ et al., 2004) because they use greater areas for roaming, as long as they remain free to roam outdoors without human supervision (SMITH et al., 1992). The cats that presented the acute phase of infection were over seven years of age, and therefore it can be suggested that cats will become more susceptible to disease through variations in hygiene habits or diet, presence of parallel infection with certain retroviruses or development of tumors that induce immune suppression. In this manner, parasite reactivation (VENTURINI et al., 1997) sometime later in life is promoted, with consequent production of immunoglobulin M. In our study, parasite reactivation seems to be the most likely event, since we could not find any fecal samples containing oocysts, even in animals positive for IgM in serum samples.

It was noted that cats that had the habit of hunting and eating raw meat had greater exposure to this parasite. It is likely that free access to raw meat increases exposure to $T$. gondii because of survival of these parasites inside chilled and refrigerated meat, which is the local way to preserve beef and beef viscera products for trade (ESPINO, 2006).

Some owners stated that although their cats were outdoor cats, they would not hunt at all because they lacked this habit. We were not able to assess the accuracy of such claims, meaning that these could be mistaken, given that hunting has been widely associated with exposure to T. gondii (VENTURINI et al., 1997; LUCAS et al., 1999; LOPES et al., 2008; LÓPEZ et al., 2011). Therefore, it can be inferred that the habit of hunting was associated with infection by $T$. gondii, and consequently, veterinarians must guide people responsible for these animals to keep them well fed and prevent their access to prey. Moreover, those responsible for cats that do hunt should be instructed to wash the litter boxes daily, to prevent development of infectious parasitic forms within feces deposited in these litter boxes and thus inhibit the parasitic cycle.

Despite the observation that $2 / 17(11.7 \%)$ of all the examined animals were in the acute phase of infection by $T$. gondii, as demonstrated by IgM levels, we were not able to find any oocysts in their stool samples. This strongly suggests that those IgM levels reflected reactivation of parasitic forms within these hosts. The results from this study suggest that despite all efforts aiming to promote healthy living habits among domestic cats and other species in urban environments, different parasitic species can still be transmitted between cats and other hosts in these environments. Thus, promoting awareness of such parasitic diseases and encouraging the development of surveillance mechanisms must be strengthened, especially regarding parasitic species such as T. gondii. It was observed that this parasite has great adaptability skills, particularly with regard to environmental conditions. Most cats receiving human care have not been exposed to the parasite before, and therefore they might be able to eliminate large amounts of oocysts if they become infected, thereby increasing the risk of household transmission. It is worth noting that animals that have been exposed to this parasite and then become reinfected usually do not eliminate oocysts at all. Even if they do so, it is only done in small amounts in their faeces (DUBEY, 1994b).

The seroprevalence of Toxoplasma gondii in cats living in the Metropolitan Region of Lima was $11 \%$. The gender of the hosts did not influence rate of exposure to the parasitic infection in this study.

The exposure to T. gondii was associated with hunting and feeding habits: those fed with raw meat were more exposed than those fed with commercial cat food or homemade food.

\section{Acknowledgements}

The authors thank the Brazilian federal funding body Coordenação de Aperfeiçoamento de Pessoal do Ensino Superior (CAPES) for awarding fellowships during the period of this work.

\section{References}

Acha PN, Szyfres B. Zoonosis y Enfermedades Transmisibles Comunes al Hombre y a los Animales. 3. ed. OPS; 2003. vol. III. Parasitosis, p. 88-96. Publicación Científica y Técnica n. 580.

Center for Disease Control and Prevention - CDC. Epi Info [online]. 2002 [cited 2012 Jan 21]. Available from: http://www.cdc. gov/epiinfo/downloads.htm.

Deeb J, Sufan M, Di Giacomo R. Toxoplasma gondii infection of cats in Beirut, Lebanon. Am J Trop Med Hyg 1985; 88(5): 301-306.

Dubey JP, Frenkel JK. Cyst-induced toxoplasmosis in cats. J Protozool 1972; 19(1): 155-177. http://dx.doi. org/10.1111/j.1550-7408.1972.tb03431.x

Dubey JP, Beattie CP. General Biology. In: Dubey JP, Beattie CP. Toxoplasmosis of Animals and Man. Boca Raton: CRC Press; 1988 p. $1-40$.

Dubey JP. Long-term persistence of Toxoplasma gondii in tissues of pigs inoculated with T. gondii oocysts and effect of freezing on viability of tissue cysts in pork. Am J Vet Res 1988; 49(6): 910-913. PMid:3400928.

Dubey JP. Toxoplasmosis. JAVMA 1994a; 205(11): 1593-1598.

Dubey JP. Toxoplasmosis and other coccidial infections. In: Sherding RG. The Cat: Diseases and Clinical Management. 2nd ed. New York: W.B. Saunders Company; 1994b. p. 565-584.

Dubey JP. Infectivity and pathogenicity of Toxoplasma gondii oocysts for cats. J Parasitol 1996; 82(6): 957-961. PMid:8973406. http://dx.doi. org/10.2307/3284206 
Espino LRS. Recuento de bacterias aerobias mesofilas totales en canales bovinas mediante el método de hisopado en un camal de Lima Metropolitana [Tesis]. Lima: Universidad Nacional Mayor de San Marcos; 2006.

Faust EC, D’Antoni JS, Odom V, Miller MJ, Peres C, Sawitz W, et al. A critical study of clinical laboratory technics for the diagnosis of protozoan cysts and helminth eggs in feces I. Preliminary communication. Am J Trop Med Hyg 1938; 18(S1): 169-183.

Garcia JL, Navarro IT, Ogawa L, Oliveira RC. Soroepidemiologia da toxoplasmose em gatos e cáes de propriedades rurais do município de Jaguapitã, Estado do Paraná, Brasil. Cienc Rural 1999; 29(1): 99-104. http://dx.doi.org/10.1590/S0103-84781999000100018

Gauss CB, Almería S, Ortuño A, Garcia F, Dubey JP. Seroprevalence of Toxoplasma gondii antibodies in domestic cats from Barcelona, Spain J Parasitol 2003; 89(5): 1067-1068. PMid:14627161. http://dx.doi. org/10.1645/GE-114

Gondim LFP, Barbosa HV Jr, Ribeiro CHA Fo, Saeki H. Serological survey of antibodies to Toxoplasma gondii in goats, sheep, cattle and water buffaloes in Bahia State, Brazil. Vet Parasitol 1999; 82(4): 273-276. http://dx.doi.org/10.1016/S0304-4017(99)00033-3

Hand M, Thatcher C, Remillard R, Roudebush P. Nutrición Clinica de los Pequeños Animales. 4th ed. Colombia: Mark Morris; 2000. p. 1341.

Leguía G. Enfermedades parasitarias de perros y gatos: Epidemiología y control. 2nd ed. Lima: La Mar; 2002.

Lopes A, Cardoso L, Rodrigues M. Serological survey of Toxoplasma gondii infection in domestic cats from northeastern Portugal. Vet Parasitol 2008; 155(3-4): 184-189. PMid:18571327. http://dx.doi. org/10.1016/j.vetpar.2008.05.007

López C, Daprato B, Zampolini S, Mazzeo C, Cardillo N, Sommerfelt I. Risk factors and prevalence of IgG antibodies to Toxoplasma gondii in domestic cats: La Matanza, Buenos Aires, Argentina. Rev Ibero-Latinoam Parasitol 2011; 70(1): 29-34.

Lucas SR, Hagiwara MK, Loureiro VD, Ikesaki JY, Birgel EH. Toxoplasma gondii infection in Brazilian domestic outpatient cats. Rev Inst Med Trop Sao Paulo 1999; 41(4): 221-224. PMid:10564914. http://dx.doi. org/10.1590/S0036-46651999000400003
Martín-Hernández I, García-Izquierdo SM. Toxoplasmosis en el hombre. Bioquimia 2003; 28(3): 19-27.

Medronho RA, Carvalho DM, Bloch KV, Luiz RR, Werneck GL. Epidemiologia. São Paulo: Atheneu; 2002. p. 493.

Mendes-de-Almeida F, Paixão RL, Labarthe NV. Superpopulação de gatos domésticos (Felis catus Linnaeus, 1758) urbanos - compreender para controlar. Clin Vet (São Paulo) 2005; 58(10): 44-48.

Miró G, Montoya A, Jiménez S, Frisuelos C, Mateo M, Fuentes I. Prevalence of antibodies to Toxoplasma gondii and intestinal parasites in stray, farm and household cats in Spain. Vet Parasitol 2004; 126(3): 249255. PMid:15567588. http://dx.doi.org/10.1016/j.vetpar.2004.08.015

Ovalle F, García A, Thibauth A, Lorca M. Frecuencia de anticuerpos anti Toxoplasma gondii en gatos de la ciudad de Valdivia, Chile. Bol Chil Parasitol 2000; 55(3-4): 94-99. PMid:11338982. http://dx.doi. org/10.4067/S0365-94022000000300012

Pena HJF, Soares RM, Amaku M, Dubey LP, Gennari SM. Toxoplasma gondii infection in cats from São Paulo state, Brazil: seroprevalence, oocyst shedding, isolation in mice, and biologic and molecular characterization. Res Vet Sci 2006; 81(1): 58-67. PMid:16289158. http://dx.doi. org/10.1016/j.rvsc.2005.09.007

Sampaio IBM. Estatística Aplicada à Experimentação Animal. 2nd ed. Belo Horizonte: FEPMVZ; 2002.

Silva AV, Cunha ELP, Meireles LR, Gottschalk S, Mota RA, Langoni H. Toxoplasmose em ovinos e caprinos: estudo soroepidemiológico em duas regióes do Estado de Pernambuco, Brasil. Cienc Rural 2003; 33(1): 115119. http://dx.doi.org/10.1590/S0103-84782003000100018

Smith K, Zimmerman J, Patton S, Beran G, Hill H. The epidemiology of toxoplasmosis on Iowa swine farms with an emphasis on the roles of free-living mammals. Vet Parasitol 1992; 42(3-4): 199-211. http://dx.doi. org/10.1016/0304-4017(92)90062-E

Venturini M, Castellano M, Bacigalupe D, Oliva G, Unzaga JM, Risso MA, et al. Coinfección con Toxoplasma gondii y virus de la inmunodeficiencia felina (FIV). Parasitol día 1997; 21(3-4): 81-84.

Wallace GD. Serologic and epidemiologic observations on toxoplasmosis on three Pacific Atolls. Am J Epidemiol 1969; 90(2): 103-111. PMid:5817004. 